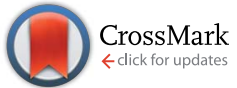

Cite this: RSC Adv., 2017, 7, 9669

Received 5th January 2017

Accepted 26th January 2017

DOI: $10.1039 / c 7 r a 00142 h$

rsc.li/rsc-advances

\section{New insights into the role of chitosan oligosaccharide in enhancing growth performance, antioxidant capacity, immunity and intestinal development of weaned pigs $\dagger$}

\author{
Jin Wan,,$^{a}$ Fei Jiang,,$^{\mathrm{a}}$ Qingsong $\mathrm{Xu},{ }^{\text {tb }}$ Daiwen Chen, ${ }^{a}$ Bing $Y u,{ }^{a}$ Zhiqing Huang, ${ }^{a}$ \\ Xiangbing Mao, ${ }^{a}$ Jie $\mathrm{Yu}^{\mathrm{a}}$ and Jun $\mathrm{He}^{* a}$
}

\begin{abstract}
Chitosan oligosaccharide (COS), an oligomer of D-glucosamine, is a vital growth stimulant in the pig industry. However, the mechanisms by which COS mediates pig growth are not fully understood. Therefore, we further investigated how COS supplementation affects pig growth. A total of 32 Landrace $\times$ Yorkshire weaned pigs were randomly divided into a control group (basal diet without COS supplementation) and a COS group (100 mg COS per kg basal diet). The pigs that ingested COS for 21 days were associated with a higher $(P<0.05)$ average daily body weight gain compared to those in the control group. Relative to the control group, the apparent digestibility of crude protein, ash, fat, dry matter and gross energy were markedly elevated $(P<0.05)$ upon COS supplementation. COS supplementation not only increased $(P<0.05)$ the activities of superoxide dismutase, catalase and total antioxidant capacity but also elevated $(P<0.05)$ interleukin-6, tumour necrosis factor- $\alpha$ and immunoglobulin $G$ concentrations in the serum. Moreover, the serum malondialdehyde concentration was decreased $(P<0.05) 26.59 \%$ by COS ingestion. COS supplementation also significantly enhanced $(P$ $<0.05$ ) secretory immunoglobulin A content, villus height and digestive enzyme activities (maltase, lactase and sucrase) in the small intestine. Intriguingly, dietary COS supplementation up-regulated $(P<$ $0.05)$ the tight junction protein claudin-1 (CLDN-1) and occludin (OCLN) mRNA abundance, as well as the $\mathrm{Na}^{+}$-glucose co-transporter 1 (SGLT1) mRNA abundance in the jejunum. Importantly, COS not only increased $(P<0.05)$ the Bifidobacterium populations in the ileum but also decreased $(P<0.05)$ the total bacteria and Escherichia coli populations in the caecum and colon. Together, these results suggest that COS supplementation can accelerate weaned pig growth through enhancing antioxidant and immune properties, as well as intestinal development.
\end{abstract}

\section{Introduction}

Antibiotics, as growth promoters and therapeutic medicine, have been used in animal production for many years. ${ }^{\mathbf{1}}$ However, there is a growing concern over the use of antibiotics in livestock industry because it has caused many adverse effects including the emergence of bacteria resistant to antibiotics and the potential of producing drug residues in animal products. ${ }^{2,3}$ Therefore, increasing attention has been paid in the feed

${ }^{a}$ Institute of Animal Nutrition, Sichuan Agricultural University, Chengdu 611130, Sichuan, People's Republic of China.E-mail: wanjin91@163.com; hejun8067@163. com; Fax: +86-28-86290920; Tel: +86-13419354223

${ }^{b}$ College of Fisheries and Life Science, Dalian Ocean University, Dalian 116023, Liaoning, People's Republic of China. E-mail: xuqingsong@dlou.edu.cn; Fax: +86411-84379061; Tel: +86-411-84763004

$\dagger$ Electronic supplementary information (ESI) available. See DOI: 10.1039/c7ra00142h

\$ Contributed equally. industry to develop safe, effective and residue-free antibiotic alternatives. Among omnifarious antibiotic alternatives, functional oligosaccharides (commonly referred to as prebiotics) are gaining outstanding consideration due to their multiple biological activities, which have potential benefits to animals. ${ }^{4,5}$

Chitosan oligosaccharide (COS) is a degradation product of chitosan prepared from the deacetylation of chitin, the second most abundant polymer in nature after cellulose ${ }^{6}$ Compared to chitosan, COS has a higher water solubility and lower viscosity, thus, it is readily absorbed through the intestine and mainly excreted in the urine. Moreover, COS has been demonstrated to possess several biological activities including anti-inflammation, ${ }^{7,8}$ anti-tumor, ${ }^{9,10}$ anti-hypertension, ${ }^{11,12}$ anti-microbial ${ }^{13,14}$ and anti-oxidation. ${ }^{15,16}$ Due to these properties, COS can be used as a pro-growth dietary supplement for animals, as well as an antibiotic alternative. ${ }^{17}$ Notably, COS has been used as a feed supplement to improve growth performance and nutrient digestibility in weaning pigs. ${ }^{18}$ COS supplementation can also 
improve the small intestinal morphology and decrease the incidence of diarrhoea in weaned pigs. ${ }^{19}$

Weaning stress has been reported to disturb intestinal health balance, which is associated with morphological and physiological changes that include intestinal inflammation, villous atrophy, crypt hyperplasia and reduced epithelial brush border activity. ${ }^{20,21}$ Additionally, a recent study indicated that weaning could induce oxidative stress, resulting in oxidative damage in pigs. ${ }^{22}$ Collectively, these factors favour diarrhoea, translocation of bacteria and reduce the digestive and absorptive capacity of small intestinal enterocytes, resulting in a decrease in daily weight gain and causing serious economic losses in the pig industry. In the past, postweaning disorders were controlled using antibiotic growth promoters in weaned pig diets. ${ }^{23}$ Currently, specific dietary interventions can offer a viable and practical alternative to antibiotics that alleviates physiological disorders after weaning. Certain nutrients, such as COS, may play an active role in maintaining the intestinal development, as well as in down-regulating oxidative stress. ${ }^{24}$ However, the causal link between COS and the improvement in pig health status remains largely unknown. Hence, further clarification is necessary.

Accordingly, the present study was conducted to elucidate how dietary COS supplementation confers beneficial effects in weaned pigs. The findings provide advanced insight into the mechanisms underlying COS-mediated weaned pig growth acceleration. Furthermore, the results suggest that using dietary nutrient components, such as COS, to enhance growth in weaned pigs deserves further attention in the future.

\section{Materials and methods}

\section{COS preparation and composition measurement}

COS was prepared by enzymatic hydrolysis of chitosan, according to a previously published method. ${ }^{25}$ Briefly, chitosan ( $\left.0.5 \mathrm{~g}\right)$ was dissolved in $2 \%$ acetic acid $(10 \mathrm{~mL})$, and the $\mathrm{pH}$ adjusted to 5.6. The enzyme mixture $(5 \mathrm{mg}$ ) pre-dissolved in $0.05 \mathrm{M}$ acetate buffer, was then added and the solution incubated at $40{ }^{\circ} \mathrm{C}$ for $40 \mathrm{~min}$. Hydrolysis was terminated by boiling for $10 \mathrm{~min}$. The hydrolysate was then filtered through a hollow fibre membrane. The filtrate containing crude COS, was added to ethanol and the mixture stirred, forming a supersaturated solution that was stored at $4{ }^{\circ} \mathrm{C}$ overnight. Subsequently, the insoluble precipitate was filtered through Whatman 1 filter paper, under vacuum. The obtained COS solution, with a concentration of approximately $20 \%$ (v/v, COS/ethanol) was concentrated by drying on a rotary evaporator and the dried COS powder was then dissolved in water. An aliquot was analysed using high-performance liquid chromatography (HPLC) and matrix-assisted laser desorptionionisation time-of-flight mass spectrometry (TOF-MS).

\section{Animals and experimental treatments}

A total of 32 healthy pigs (Landrace $\times$ Yorkshire), weaned at 28 days with an initial body weight of $7.78( \pm 0.09) \mathrm{kg}$ were randomly assigned to two treatments $(n=16)$. The dietary treatment groups were as follows: (1) a basal corn-soybean diet (control, CON) and (2) the basal diet supplemented with $100 \mathrm{mg} \mathrm{kg}^{-1} \mathrm{COS}$ (termed COS).
Table 1 Ingredient and nutrient composition of piglet basal diet (asfed basis)

\begin{tabular}{lc}
\hline & $\begin{array}{l}\text { Content } \\
\text { Ingredient }\end{array}$ \\
\hline Extruded corn (7.8\% crude protein) & 24.00 \\
Corn $(7.8 \%$ crude protein) & 27.70 \\
Soybean meal (44.2\% crude protein) & 13.50 \\
Extruded soybean & 10.50 \\
Whey powder (low protein) & 7.00 \\
Soybean protein concentrate & 5.00 \\
Fish meal $(62.5 \%$ crude protein) & 4.00 \\
Sucrose & 4.00 \\
Soybean oil & 1.50 \\
Limestone & 0.90 \\
Dicalcium phosphate & 0.60 \\
L-Lysine HCl $(78 \%)$ & 0.30 \\
Salt & 0.30 \\
Chloride choline & 0.10 \\
DL-Methionine & 0.08 \\
L-Threonine $(98.5 \%)$ & 0.06 \\
Tryptophan & 0.02 \\
Mineral premix & $a$ \\
Vitamin premix & \\
Total & 0.40 \\
& 0.04
\end{tabular}

Calculated composition

Dietary energy $\left(\mathrm{MJ} \mathrm{kg}^{-1}\right)$

Crude protein $\quad 19.93$

Calcium $\quad 0.85$

Total phosphorus $\quad 0.62$

Available phosphorus $\quad 0.44$

Lysine $\quad 1.33$

Methionine $\quad 0.39$

Methionine + cysteine $\quad 0.66$

$\begin{array}{ll}\text { Threonine } & 0.78\end{array}$

${ }^{a}$ The mineral premix provided the following per $\mathrm{kg}$ of diets: $75 \mathrm{mg} \mathrm{Fe}$ from ferrous sulphate, $150 \mathrm{mg} \mathrm{Cu}$ from copper sulphate, $75 \mathrm{mg} \mathrm{Zn}$ from zinc sulphate, $60 \mathrm{mg}$ Mn from manganese sulphate, $0.35 \mathrm{mg}$ I from calcium iodide and $0.35 \mathrm{mg}$ Se from sodium selenite. ${ }^{b}$ The vitamin premix provided the following per $\mathrm{kg}$ of diets: $9000 \mathrm{IU}$ vitamin (V) A, $3000 \mathrm{IU} \mathrm{VD}_{3}, 20 \mathrm{IU} \mathrm{VE}, 3 \mathrm{mg} \mathrm{VK} 3,1.5 \mathrm{mg} \mathrm{VB}, 4 \mathrm{mg}$

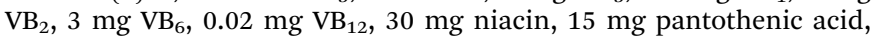
$0.75 \mathrm{mg}$ folic acid and $0.10 \mathrm{mg}$ biotin.

All pigs were housed in individual metabolism cages $(0.7 \times$ $1.5 \mathrm{~m})$ in a temperature-controlled nursery $\left(24-26^{\circ} \mathrm{C}\right)$ during the entire 3 week experimental period. On days $18-21$, the nutrient digestibility was measured using acid insoluble ash (AIA) as an endogenous indicator. The diets were formulated to meet or exceed the nutrient requirements recommended by the National Research Council (NRC) (2012), ${ }^{26}$ and their compositions are shown in Table 1 . Throughout the experimental periods, the pigs were fed their respective diets three times per day at 8:00, 13:00 and 18:00 h. Water and feed were provided ad libitum to the pigs and the pigs were exposed to natural lighting throughout the experiment.

\section{Growth performance measurement}

Individual pig body weight was recorded at the start and end of the experiment, before feeding. All feed remaining in the feed trough at the next feeding was weighed and subtracted from the 
daily allowance to determine actual daily feed intake. Average daily body weight gain (ADG), average daily feed intake (ADFI) and the ratio of feed to gain $(\mathrm{F} / \mathrm{G})$ were calculated from the values described above.

\section{Sample collection and preparation}

Representative feed samples from each dietary treatment were collected and stored at $-20{ }^{\circ} \mathrm{C}$ until chemical analysis. Faecal samples were collected from days 18-21 during the trial, to determine the apparent nutrient digestibility (crude protein, crude ash, crude fat, dry matter, gross energy, calcium and phosphorus). After each collection, $10 \% \mathrm{HCl}$ was added for fixation of excreta nitrogen. Faeces, from 4 days of each replicate, were mixed thoroughly and dried at $60{ }^{\circ} \mathrm{C}$ for $72 \mathrm{~h}$, then ground to pass through a $1 \mathrm{~mm}$ screen and stored at $-20{ }^{\circ} \mathrm{C}$ to analyse the key nutrient contents.

At 08:00 h on day 22, after an overnight fast, blood samples were collected from the precaval vein into non-heparinised vacuum tubes and centrifuged $(3000 \times g)$ at $4{ }^{\circ} \mathrm{C}$ for $10 \mathrm{~min}$. After bleeding, all pigs were electrical stunned and killed by exsanguination, the abdomen was immediately opened to collect the digesta and intestinal sections from the gastrointestinal tract. Approximately $2 \mathrm{~cm}$ segments from the same duodenal, jejunal and ileal sections were rinsed several times with ice-cold phosphate-buffered saline, and then stored in $4 \%$ paraformaldehyde solution for histological analyses. Thereafter, the rest of the duodenum, jejunum and ileum were taken to collect mucosal scrapings that were immediately snap-frozen and stored at $-80{ }^{\circ} \mathrm{C}$, pending measurement of the digestive enzyme activities, secretory IgA (sIgA) content and quantitative real-time polymerase chain reaction (qPCR) analysis. Finally, digesta from the ileum, caecum and colon were collected and stored at $-80{ }^{\circ} \mathrm{C}$ for microbial population measurements.

\section{Chemical analyses}

The apparent nutrient digestibility was measured using AIA as the indicator. The AIA in diets and faecal samples was determined as described by the Standards Press of China (2009). ${ }^{27}$ All diet and faecal samples were analysed for dry matter (method 930.15), crude protein (method 990.03), crude fat (method 945.16), crude ash (method 942.05), calcium (method 927.02) and phosphorus (method 995.11), as described by the AOAC (1995). ${ }^{28}$ Gross energy was determined using an oxygen bomb calorimeter (Parr Instrument Co., Moline, IL, USA). The apparent nutrient digestibility $(\%)=100-A_{1} F_{2} / A_{2} F_{1} \times 100$, where $A_{1}$ represents the AIA content of the diet; $A_{2}$ represents the AIA content of faeces; $F_{1}$ represents the nutrient content of the diet and $F_{2}$ represents the nutrient content of faeces.

\section{Biochemical analysis of serum}

Analyses of cytokines and immunoglobulins. Porcinespecific ELISA kits (Cell Biolabs, San Diego, CA, USA) were used to quantify the serum inflammatory factors (interleukin (IL)-1, IL-6, IL-10 and tumour necrosis factor (TNF)- $\alpha$ ) and the immunoglobulin (IgA, IgG and IgM) concentrations, in accordance with the manufacturer's instructions. Inflammatory factors and immunoglobulin concentrations were presented as pg $\mathrm{mL}^{-1}$ and $\mu \mathrm{g} \mathrm{mL}^{-1}$ of serum, respectively.

Measurements of antioxidant-related indices. The effects of COS ingestion on the antioxidative reactions, were determined by measuring several antioxidants in the serum, such as glutathione peroxidase (GSH-Px), superoxide dismutase (SOD), catalase (CAT), as well as total antioxidant capacity (T-AOC) and malondialdehyde (MDA) content. All corresponding detection kits used in the present study were supplied by the Nanjing Jiancheng Bioengineering Institute (Nanjing, China).

GSH-Px activity was assessed according to the method of Zhang et al. ${ }^{29}$ by quantifying the rate of hydrogen peroxide $\left(\mathrm{H}_{2} \mathrm{O}_{2}\right)$ induced oxidation of reduced glutathione (GSH) to oxidised glutathione (GSSG). A yellow product, with absorbance at $412 \mathrm{~nm}$, was formed on reaction of GSH with 5,5'-dithiobis-(2-nitrobenzoic acid). One unit (U) of GSH-Px was defined as the amount that reduced the level of GSH by $1 \mu \mathrm{mol} \mathrm{L}^{-1}$ in $1 \mathrm{~min}$ per $\mathrm{mL}$ serum. Serum GSH-Px activity was expressed as $\mathrm{U} \mathrm{mL}^{-1}$ serum.

SOD activity was measured spectrophotometrically at $550 \mathrm{~nm}$ using a method described in a previous study. ${ }^{30}$ In this technique, superoxide ions are generated by the xanthine/ xanthine oxidase system, which react with 2-(4-iodophenyl)-3(4-nitrophenol)-5-phenyltetrazolium chloride to form a red formazan dye, used as the detector. SOD activity, which inhibits the formation of the formazan dye, was presented as $\mathrm{U} \mathrm{mL}^{-1}$ serum, and $1 \mathrm{U}$ of SOD denotes $50 \%$ of inhibition of superoxide ion production in the reaction.

CAT activity was examined using the colourimetric method described by Özmen et al. ${ }^{31}$ The enzymatic reaction was terminated by the addition of ammonium molybdate, which generated a light-yellow composite that could be measured at $405 \mathrm{~nm}$. CAT activity was expressed as $\mathrm{U} \mathrm{mL}^{-1}$ serum, and $1 \mathrm{U}$ of CAT defines the amount of enzyme needed to decrease $1 \mathrm{mmol} \mathrm{L}^{-1}$ of $\mathrm{H}_{2} \mathrm{O}_{2}$ at $37^{\circ} \mathrm{C}$ for $1 \mathrm{~s}$ per $\mathrm{mL}$ serum.

T-AOC determination enabled the evaluation of the total activities of several parameters, including the polyphenol complexes, protein thiol groups, vitamin $\mathrm{C}$, vitamin $\mathrm{E}$, and glutathione, all of which can convert $\mathrm{Fe}^{3+}$ to $\mathrm{Fe}^{2+} . \mathrm{Fe}^{2+}$ can then combine with phenanthroline to form stable and coloured chelates. T-AOC was estimated at $550 \mathrm{~nm}$ and expressed as U $\mathrm{mL}^{-1}$ serum. In this assay, $1 \mathrm{U}$ represents a 0.01 increase in the absorbance value in $1 \mathrm{~min}$ per $\mathrm{mL}$ serum.

MDA content was examined according to a procedure used by Livingstone et al., ${ }^{32}$ whereby MDA reacts with thiobarbituric acid (TBA) in an acidic medium at $95{ }^{\circ} \mathrm{C}$ for $30 \mathrm{~min}$. The pink product was spectrophotometrically determined at $532 \mathrm{~nm}$. The MDA content was expressed as nmol $\mathrm{mL}^{-1}$ serum.

\section{Duodenal, jejunal and ileal histomorphological studies}

A $1 \mathrm{~cm}$ long segment of the small intestine (including the duodenum, jejunum and ileum) was mixed in $10 \%$ neutral buffered formaldehyde. The mixed tissue samples were dehydrated with normal saline and then embedded in paraffin. Cross sections of each sample were prepared, stained with haematoxylin and eosin (H\&E) and then sealed by a neutral resin size. Ultrathin sections of the duodenal, jejunal and ileal 
samples were examined for the villus height and crypt depth with image processing and analysis system (Media Cybernetics, Bethesda, MD, USA). Villus height was calculated from the tip of the villi to the villus-crypt junction. ${ }^{33}$ Crypt depth was expressed as the invaginated depth between adjacent villi. A total of 10 intact, well-oriented crypt-villus units were analysed in triplicate per segment. The ratio of villus height to crypt depth (V/C) was calculated from the values described above.

\section{Intestinal mucosal sIgA and digestive enzyme assay}

Approximately $1 \mathrm{~g}$ of mucosal scrapings was suspended in $9 \mathrm{~mL}$ of ice-cold normal saline and mixed using an ultrasonic homogeniser. After centrifugation at $3000 \times g, 4{ }^{\circ} \mathrm{C}$, for $15 \mathrm{~min}$, the supernatant was removed and stored at $-20^{\circ} \mathrm{C}$. The protein concentration of the mucosal homogenates was measured using the Bradford method. ${ }^{34}$ Then, sIgA content was analysed using a porcine ELISA assay kit (Beijing 4A Biotech Co., Ltd., Beijing, China). The results were presented as $\mathrm{mg}$ sIgA/g intestinal protein. Digestive enzymes (lactase, sucrase and maltase) activities were analysed using commercial kits (Nanjing Jiancheng Bioengineering Institute, Nanjing, China) and the results expressed as $\mathrm{U}$ per $\mathrm{mg}$ protein. One $\mathrm{U}$ of digestive enzyme activity was defined as $1 \mathrm{nmol}$ of substrate hydrolysed per $1 \mathrm{mg}$ of intestinal protein per $1 \mathrm{~min}$. All procedures were performed according to the manufacturer's directions.

\section{Total RNA extraction and reverse transcription reaction}

Total RNA from the duodenal, jejunal and ileal mucosa were isolated using Trizol reagent (TaKaRa, Dalian, China) according to the manufacturer's instructions. The concentration and purity of total RNA were measured spectrophotometrically (Beckman Colter DU 800, Beckman Coulter Inc, Brea, USA). The $\mathrm{OD}_{260}: \mathrm{OD}_{280}$ ratio (where $\mathrm{OD}$ is the optical density) ranged from 1.8-2.0 in all RNase-free water-treated RNA samples, which was considered a very low degree of contamination. ${ }^{35}$ The integrity of RNA was verified by electrophoresis on $1.0 \%$ agarose gels and the 28S:18S ribosomal RNA band ratio was determined as $\geq 1$.8. Reverse transcription reactions were performed using the PrimeScript ${ }^{\mathrm{TM}}$ RT reagent kit (TaKaRa, Dalian, China), following the manufacturer's instructions.

\section{qPCR}

Claudin-1 (CLDN-1), occludin (OCLN), zonula occludens-1 (ZO-1), $\mathrm{Na}^{+}$-glucose co-transporter 1 (SGLT1) and facilitated glucose transporter 2 (GLUT2) mRNA abundance in the duodenum, jejunum and ileum were analysed by qPCR using SYBR® Green I PCR reagents (TaKaRa, Dalian, China) and the CFX96 Real-Time PCR Detection System (Bio-Rad Laboratories, Richmond, CA, USA), as described by Wan et al. ${ }^{36}$ Briefly, the gene-specific primers used were synthesised commercially by Invitrogen (Shanghai, China) and are listed in Table 2. The PCR system was composed of $5 \mu \mathrm{L}$ SYBR® Premix Ex Taq $^{\text {TM }}$ II (Tli RNaseH Plus, $2 \times), 1 \mu \mathrm{L}$ of forward and $1 \mu \mathrm{L}$ of reverse primers $(4 \mu \mathrm{M}), 2 \mu \mathrm{L}$ diethylpyrocarbonate-treated water and $1 \mu \mathrm{L}$ cDNA. Cycling conditions were as follows: $95{ }^{\circ} \mathrm{C}$ for $10 \mathrm{~s}$, followed by forty cycles at $95{ }^{\circ} \mathrm{C}$ for $5 \mathrm{~s}, 10 \mathrm{~s}$ at the annealing temperature (Table 2) and at
$72{ }^{\circ} \mathrm{C}$ for $15 \mathrm{~s}$. The melting curve conditions were $95{ }^{\circ} \mathrm{C}$ for $30 \mathrm{~s}$, $55{ }^{\circ} \mathrm{C}$ for $1 \mathrm{~min}$ and $95{ }^{\circ} \mathrm{C}$ for $1 \mathrm{~min}$, which was carried out after each qPCR to verify the specificity and purity of all the PCR products. Each sample was run simultaneously in triplicate on the same PCR plate. The average value of each triplicate expressed as the number of copies was used for the statistical analysis. A standard curve was established using serial dilutions of one of the complementary DNA samples, which allowed obtaining reliable amplification efficiency values (from 90-110\%). For normalisation, $\beta$-actin was chosen as the reference gene because no variation in its expression was observed between treatments. The relative mRNA abundance of the analysed genes was calculated using the $2^{-\Delta \Delta \mathrm{Ct}}$ method, ${ }^{37}$ and the messenger RNA (mRNA) level of each target gene for the CON group was set to 1.0.

\section{Microbial population determination}

Bacterial DNA was extracted from ileal, caecal and colonic digesta using the Stool DNA Kit (Omega Bio-Tek, Doraville, CA, USA) according to the manufacturer's instructions. Primers and probes (Table 2) were designed with Primer Premier 5.0 (Premier Biosoft International, Palo Alto, CA) and followed 16S rRNA sequences of maximum species of each genus homology downloaded from GenBank database, European Molecular Biology Laboratory and DNA Data Bank of Japan to obtain specific amplification. The sequences of all the genera taken from the database were examined in DNASTAR MegAlign program (Madison, WI), as described by Wan et al. ${ }^{38}$ Next, these sequences were submitted to alignment, in which the maximum number of species belonging to one genus was gathered and the regions showing conservations were picked up as genus-specific primers and probes. All the primers and probes used in this experiment were commercially synthesised by Invitrogen (Shanghai, China).

qPCR was conducted using a CFX96 Real-Time PCR System (Bio-Rad Laboratories, Inc., Hercules, CA, USA) with opticalgrade 96-well plates. For the quantification of total bacteria, the reaction mixture $(25 \mu \mathrm{L})$ contained $1 \mu \mathrm{L}$ forward and $1 \mu \mathrm{L}$ reverse primers (100 nM), $12.5 \mu \mathrm{L}$ SYBR $®$ Premix Ex Taq ${ }^{\mathrm{TM}}$ II (Tli RNaseH Plus, $2 \times$ ), $1 \mu \mathrm{L}$ template DNA and $9.5 \mu \mathrm{L}$ nuclease-free water. The thermal cycling conditions were an initial predenaturation step at $95{ }^{\circ} \mathrm{C}$ for $10 \mathrm{~s}, 40$ cycles of denaturation at $95{ }^{\circ} \mathrm{C}$ for $5 \mathrm{~s}$, annealing at $60.0^{\circ} \mathrm{C}$ for $25 \mathrm{~s}$ and extension at $72{ }^{\circ} \mathrm{C}$ for $60 \mathrm{~s}$. For the quantification of Escherichia coli, Lactobacillus, Bifidobacterium and Bacillus, qPCR was conducted in a reaction volume of $20 \mu \mathrm{L}$ with $1 \mu \mathrm{L}$ probe enhancer solution $(20 \times), 0.3 \mu \mathrm{L}$ probe $(100 \mathrm{nM}), 1 \mu \mathrm{L}$ forward and $1 \mu \mathrm{L}$ reverse primers $(100$ $\mathrm{nM}), 8 \mu \mathrm{L}$ RealMasterMix $(2.5 \times$; Tiangen, Beijing, China), $1 \mu \mathrm{L}$ template DNA and $7.7 \mu \mathrm{L}$ nuclease-free water. The PCR conditions involved $95{ }^{\circ} \mathrm{C}$ for $10 \mathrm{~s}$ and 50 cycles at $95{ }^{\circ} \mathrm{C}$ for $5 \mathrm{~s}, 25 \mathrm{~s}$ at the annealing temperature (Table 2 ) and finally at $72{ }^{\circ} \mathrm{C}$ for $60 \mathrm{~s}$. The threshold cycle $(\mathrm{Ct})$ values and baseline settings were determined by automatic analysis settings, and the copy numbers of the target group for each reaction were calculated from the standard curves.

For the quantification of bacteria in the test samples, specific standard curves were generated by constructing 
Table 2 Sequences of primers and probes used for quantitative real-time $\mathrm{PCR}^{a}$

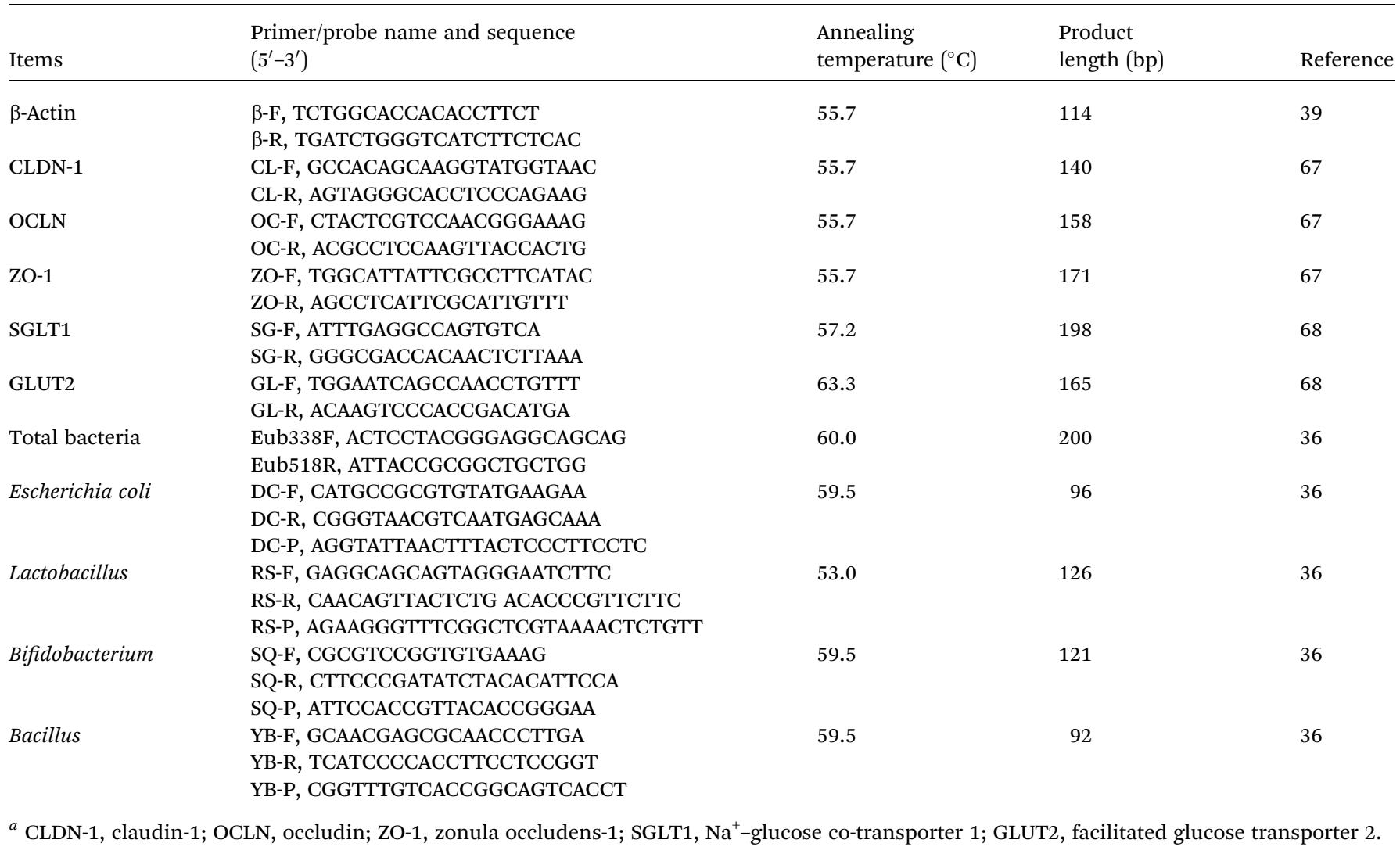

standard plasmids, as presented by Han et al. ${ }^{39}$ Deoxyribonucleic acid concentrations of standard plasmids were detected using a spectrophotometer (Beckman Colter DU 800, Beckman Coulter Inc, Brea, USA). A series of tenfold dilution (1 $\times 10^{9}$ to $1 \times 10^{1}$ copies per $\mu \mathrm{L}$ ) of plasmid DNA were used to construct their respective standard curves. Each standard curve was generated by a linear regression of the plotted points with the logarithm of template copy numbers as the abscissa and the $\mathrm{Ct}$ values as the ordinate. The gene copy numbers were calculated by the following formula: $\left(6.0233 \times 10^{23}\right.$ copies per mol $\times$ DNA concentration $\left.\left(\mu \mathrm{g} \mu \mathrm{L}^{-1}\right)\right) /\left(660 \times 10^{6} \times\right.$ DNA size (bp)).

\section{Statistical analysis}

Bacterial copies were transformed $\left(\log _{10}\right)$ before the statistical analysis. Each pig was considered as an experimental unit for analyses. All data were analysed by a $t$-test using SAS (version 9.0; SAS Inst. Inc., Cary, NC, USA). Data are presented as the mean \pm standard error, and $P$-values $<0.05$ were used to indicate statistical significance.

\section{Results}

\section{COS composition}

The HPLC and TOF-MS results are shown in Supplementary Fig. S1A and S1B, $\uparrow$ respectively. COS was a mixture of several oligosaccharides, with a degree of deacetylation $>95 \%$ and an average molecular weight $\leq 1000 \mathrm{Da}$. It had a degree of polymerisation (DP) of $2-8$ in the mixture, with weight percentages of $5.5,21.1,31.5,26.7,10.9,2.9$ and $1.3 \%$, respectively. The ${ }^{13} \mathrm{C}$ NMR $\left(\mathrm{D}_{2} \mathrm{O}, 100 \mathrm{MHz}\right)$ spectra were obtained using a Bruker AV600 MHz (ESI Fig. S2A $\dagger$ ). The single peaks at 182.54 and $175.71 \mathrm{ppm}$ were assigned to discrete $\mathrm{CH}_{3} \mathrm{CO}$ sites of COS, respectively. Multiplets from 90.15$102.47 \mathrm{ppm}$ corresponded to anomeric carbon signals, while multiplets from 55.39-79.80 ppm represented other sugar ring carbon signals, respectively. The single peaks at $24.65 \mathrm{ppm}$ were attributed to $\mathrm{CH}_{3} \mathrm{CO}$. The ${ }^{1} \mathrm{H}$ NMR $\left(\mathrm{D}_{2} \mathrm{O}, 400\right.$ $\mathrm{MHz})$ spectra are shown in ESI Fig. S2B. $\uparrow$ The resonances at 2.02 and $5.39 \mathrm{ppm}$ were assigned to the $\mathrm{N}$-acetyl and $\mathrm{H}-1$ protons of the GlcNAc residue, respectively. The $\mathrm{H}-2$ proton of the $\mathrm{GlCNH}_{2}$ units was found at $3.04 \mathrm{ppm}$. Multiplets from 3.25-3.98 ppm corresponded to $\mathrm{H}-3-6$ of the methine protons of COS, respectively.

\section{Growth performance}

Based on the results listed in Table 3, we demonstrated that during the overall period, the COS-supplemented pigs had greater $(P<0.05)$ ADG compared to those in the control group. However, throughout the whole experimental period, no differences $(P>0.05)$ were found between the two groups regarding the ADFI and F/G. 
Table 3 Effects of chitosan oligosaccharide on the growth performance of weaned pigs over the experimental period ${ }^{a, b}$

\begin{tabular}{|c|c|c|c|}
\hline \multirow[b]{2}{*}{ Items } & \multicolumn{2}{|l|}{ Treatments $^{c}$} & \multirow[b]{2}{*}{$P$-Value } \\
\hline & $\mathrm{CON}$ & $\cos$ & \\
\hline \multicolumn{4}{|l|}{ Days 1-21 } \\
\hline $\mathrm{ADG}^{d}(\mathrm{~g})$ & $476.05 \pm 15.67$ & $516.83 \pm 10.37^{*}$ & 0.038 \\
\hline $\mathrm{ADFI}^{e}(\mathrm{~g})$ & $704.99 \pm 20.00$ & $748.81 \pm 13.40$ & 0.079 \\
\hline $\mathrm{F} / \mathrm{G}^{f}$ & $1.49 \pm 0.03$ & $1.45 \pm 0.01$ & 0.221 \\
\hline \multicolumn{4}{|c|}{ 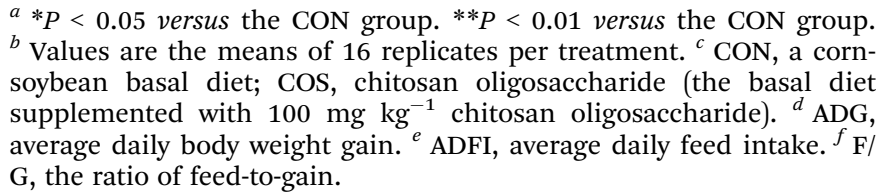 } \\
\hline
\end{tabular}

\section{Apparent nutrient digestibility}

According to Table 4, we found pigs in the COS group had a higher $(P<0.05)$ apparent digestibility of crude protein, ash, fat and dry matter than pigs in the CON group. Also, the energy utilisation in the COS group was greater $(P<0.05)$ compared to the CON group. In addition, the apparent digestibility of calcium and phosphorus did not differ $(P>0.05)$ between the treatment groups.

\section{Antioxidant parameters}

The serum antioxidant parameter results, after dietary treatment, are shown in Table 5. Although supplementation with COS had no effect $(P>0.05)$ on serum GSH-Px activity, it significantly enhanced $(P<0.05)$ serum SOD, CAT and T-AOC activities by $11.25,50.66$ and $14.35 \%$, respectively. Moreover, MDA content in the serum was notably decreased $(P<0.05)$ by COS supplementation.

\section{Immune indices}

After dietary COS inclusion, higher $(P<0.05)$ IL-6, TNF- $\alpha$ and IgG concentrations in the serum were observed (Table 6). Simultaneously, COS inclusion elevated $(P<0.05)$ sIgA content in all of the selected intestinal segments. Moreover, the pro-

Table 4 Effects of chitosan oligosaccharide on the apparent digestibility of nutrients in weaned pigs ${ }^{a, b}$

\begin{tabular}{llll}
\hline & \multicolumn{2}{l}{ Treatments $^{c}$} & \\
\cline { 2 - 3 } Items & CON & COS & P-Value \\
\hline Crude protein & $72.42 \pm 1.14$ & $80.19 \pm 1.08^{* *}$ & $<0.001$ \\
Crude ash & $35.51 \pm 1.79$ & $45.00 \pm 2.29^{* *}$ & 0.003 \\
Crude fat & $51.47 \pm 1.96$ & $58.45 \pm 1.77^{*}$ & 0.013 \\
Dry matter & $80.01 \pm 0.63$ & $84.71 \pm 0.74^{* *}$ & $<0.001$ \\
Gross energy & $76.65 \pm 0.61$ & $81.00 \pm 1.14^{* *}$ & 0.003 \\
Calcium & $55.59 \pm 1.31$ & $57.61 \pm 0.99$ & 0.232 \\
Phosphorus & $45.03 \pm 1.28$ & $47.95 \pm 1.25$ & 0.117
\end{tabular}

$a{ }^{*} P<0.05$ versus the CON group. ${ }^{* *} P<0.01$ versus the CON group. ${ }^{b}$ Values are the means of 16 replicates per treatment. ${ }^{c} \mathrm{CON}$, a cornsoybean basal diet; COS, chitosan oligosaccharide (the basal diet supplemented with $100 \mathrm{mg} \mathrm{kg}^{-1}$ chitosan oligosaccharide).
Table 5 Effects of chitosan oligosaccharide on the serum antioxidant status of weaned pigs ${ }^{a, b}$

\begin{tabular}{|c|c|c|c|}
\hline \multirow[b]{2}{*}{ Items } & \multicolumn{2}{|l|}{ Treatments $^{c}$} & \multirow[b]{2}{*}{$P$-Value } \\
\hline & $\mathrm{CON}$ & $\cos$ & \\
\hline GSH-Px ${ }^{d}\left(\mathrm{U} \mathrm{mL}^{-1}\right)$ & $396.33 \pm 5.73$ & $407.00 \pm 6.43$ & 0.231 \\
\hline $\operatorname{SOD}^{e}\left(\mathrm{U} \mathrm{mL}^{-1}\right)$ & $51.36 \pm 1.45$ & $57.14 \pm 1.05^{*}$ & 0.005 \\
\hline $\operatorname{CAT}^{f}\left(\mathrm{U} \mathrm{mL}^{-1}\right)$ & $4.58 \pm 0.22$ & $6.90 \pm 0.27 * *$ & $<0.001$ \\
\hline $\mathrm{T}-\mathrm{AOC}^{g}\left(\mathrm{U} \mathrm{mL}^{-1}\right)$ & $4.25 \pm 0.10$ & $4.86 \pm 0.08^{* *}$ & $<0.001$ \\
\hline $\operatorname{MDA}^{h}\left(\mathrm{~nm} \mathrm{~mL}^{-1}\right)$ & $4.40 \pm 0.19$ & $3.23 \pm 0.13^{* *}$ & $<0.001$ \\
\hline
\end{tabular}

$a *_{P}<0.05$ versus the CON group. ${ }^{* *} P<0.01$ versus the CON group. ${ }^{b}$ Values are the means of 16 replicates per treatment. ${ }^{c} \mathrm{CON}$, a cornsoybean basal diet; COS, chitosan oligosaccharide (the basal diet supplemented with $100 \mathrm{mg} \mathrm{kg}{ }^{-1}$ chitosan oligosaccharide). ${ }^{d}$ GSH-Px, glutathione peroxidase. ${ }^{e}$ SOD, superoxide dismutase. ${ }^{f} \mathrm{CAT}$, catalase. ${ }_{g}^{g}$ T-AOC, total antioxidant capacity. ${ }^{h}$ MDA, malondialdehyde.

inflammatory cytokine, IL-1, and the anti-inflammatory cytokine, IL-10, as well as the IgA and IgM serum contents, were unaffected $(P>0.05)$ by dietary treatment.

\section{Intestinal mucosal morphology}

Fig. 1 presents the H\&E staining results of the duodenum, jejunum and ileum. We confirmed that COS ingestion caused structural duodenal change but failed to cause jejunal and ileal morphological alterations.

We further calculated the duodenal, jejunal and ileal villus height and crypt depth for the two groups (Table 7). Specifically, COS supplementation promoted an increase $(P<0.05)$ in the duodenal villus height by $4.65 \%$, compared to the CON group.

Table 6 Effects of chitosan oligosaccharide on the immune responses of weaned pigs ${ }^{a, b}$

\section{Treatments}

$\begin{array}{lll}\text { Items } & \mathrm{CON} & \mathrm{COS}\end{array}$

\section{Serum}

$\mathrm{IL}-1^{d}\left(\mathrm{pg} \mathrm{mL} \mathrm{m}^{-1}\right)$

$\mathrm{IL}-10^{f}\left(\mathrm{pg} \mathrm{mL} \mathrm{m}^{-1}\right)$ TNF- $\alpha^{g}\left(\mathrm{pg} \mathrm{mL} \mathrm{m}^{-1}\right)$ $\operatorname{IgG}^{h}\left(\mu \mathrm{g} \mathrm{mL} \mathrm{m}^{-1}\right)$ $\operatorname{IgA}^{i}\left(\mu \mathrm{g} \mathrm{mL}^{-1}\right)$ $\operatorname{IgM}^{j}\left(\mu \mathrm{g} \mathrm{mL}^{-1}\right)$

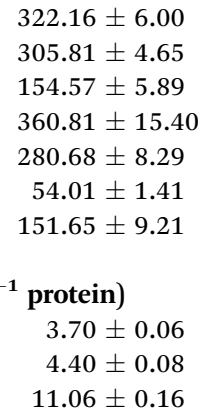

$\mathrm{IL}^{-} 6^{e}\left(\mathrm{pg} \mathrm{mL} \mathrm{mL}^{-1}\right)$
0.295

$<0.001$

0.094

0.022

0.008

0.128

0.059 $a * P<0.05$ versus the CON group. ${ }^{* *} P<0.01$ versus the CON group. ${ }^{b}$ Values are the means of 16 replicates per treatment. ${ }^{c} \mathrm{CON}$, a cornsoybean basal diet; COS, chitosan oligosaccharide (the basal diet supplemented with $100 \mathrm{mg} \mathrm{kg}^{-1}$ chitosan oligosaccharide). ${ }^{d} \mathrm{IL}-1$, interleukin-1. ${ }^{e}$ IL-6, interleukin-6. ${ }^{f}$ IL-10, interleukin-10. ${ }^{g}$ TNF- $\alpha$, tumour necrosis factor- $\alpha .{ }^{h}$ IgG, immunoglobulin G. ${ }^{i}$ IgA, immunoglobulin A. ${ }^{j}$ IgM, immunoglobulin M. ${ }^{k}$ sIgA, secretory immunoglobulin A. 


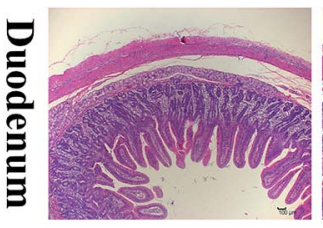

CON

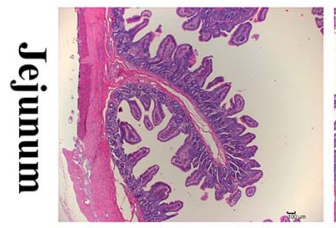

CON

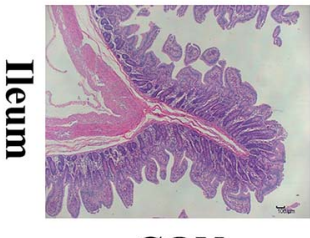

CON

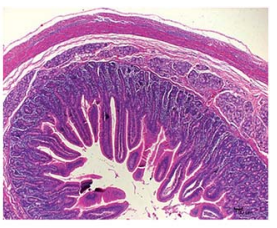

COS

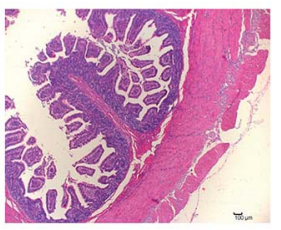

$\operatorname{COS}$

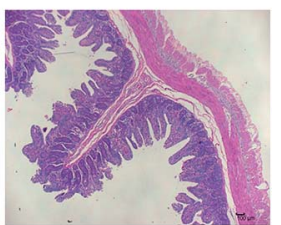

$\operatorname{COS}$
Fig. 1 Histological evaluation of small intestine tissues $(H \& E ; \times 40)$ in weaned pigs after exposure to chitosan oligosaccharide. CON, a cornsoybean basal diet; COS, chitosan oligosaccharide (the basal diet supplemented with $100 \mathrm{mg} \mathrm{kg}^{-1}$ chitosan oligosaccharide). Scale bar is $100 \mu \mathrm{m}$.

\section{Digestive enzyme activities}

The effects of COS on the digestive enzyme activities are presented in Table 8. Compared to the CON group, COS-supplemented pigs had a higher maltase activity $(P<0.05)$ in the jejunal mucosa, but not $(P>0.05)$ in the duodenal and ileal mucosa. On the contrary,

Table 7 Effects of chitosan oligosaccharide on the intestinal mucosa morphology of weaned pigs ${ }^{a, b}$

\begin{tabular}{llll} 
& \multicolumn{2}{l}{} & \\
\cline { 2 - 3 } Ireatments & & \\
Items & $\mathrm{CON}$ & $\mathrm{COS}$ & $P$-Value
\end{tabular}

\section{Duodenum}

Villus height $(\mu \mathrm{m})$

Crypt depth $(\mu \mathrm{m})$

$\mathrm{V} / \mathrm{C}^{d}$

$$
\begin{aligned}
484.16 & \pm 5.56 \\
234.70 & \pm 3.17 \\
2.07 & \pm 0.03
\end{aligned}
$$

$\begin{aligned} 506.65 & \pm 4.32^{* *} \\ 240.90 & \pm 4.81 \\ 2.12 & \pm 0.05\end{aligned}$

0.003

0.290

0.403

\section{Jejunum}

Villus height $(\mu \mathrm{m})$

Crypt depth $(\mu \mathrm{m})$

$$
\begin{aligned}
314.39 & \pm 12.09 \\
147.40 & \pm 6.43 \\
2.17 & \pm 0.09
\end{aligned}
$$

$$
\begin{array}{r}
321.51 \pm 6.23 \\
136.39 \pm 5.19 \\
2.40 \pm 0.08
\end{array}
$$

0.606

0.193

0.062

Ileum

Villus height $(\mu \mathrm{m})$

Crypt depth $(\mu \mathrm{m})$

$$
\begin{aligned}
467.42 & \pm 10.28 \\
195.36 & \pm 5.78 \\
2.43 & \pm 0.10
\end{aligned}
$$

\begin{tabular}{|c|c|c|c|}
\hline \multirow[b]{2}{*}{ Items } & \multicolumn{2}{|l|}{ Treatments $^{c}$} & \multirow[b]{2}{*}{$P$-Value } \\
\hline & $\mathrm{CON}$ & $\cos$ & \\
\hline \multicolumn{4}{|c|}{ Duodenum ( $\mathrm{U} \mathbf{m g}^{-1}$ protein) } \\
\hline Maltase & $226.33 \pm 7.04$ & $239.94 \pm 8.10$ & 0.225 \\
\hline Lactase & $44.50 \pm 1.37$ & $51.77 \pm 1.52^{* *}$ & 0.003 \\
\hline Sucrase & $24.22 \pm 0.78$ & $26.94 \pm 0.92 *$ & 0.041 \\
\hline \multicolumn{4}{|c|}{ Jejunum ( $\mathrm{U} \mathbf{~ m g}^{-1}$ protein) } \\
\hline Maltase & $207.18 \pm 7.34$ & $230.94 \pm 7.32^{*}$ & 0.038 \\
\hline Lactase & $189.41 \pm 9.20$ & $220.37 \pm 9.75^{*}$ & 0.037 \\
\hline Sucrase & $104.88 \pm 4.73$ & $117.58 \pm 3.53$ & 0.050 \\
\hline \multicolumn{4}{|c|}{ Ileum ( $\mathrm{U} \mathrm{mg}^{-1}$ protein) } \\
\hline Maltase & $212.96 \pm 5.99$ & $224.11 \pm 7.37$ & 0.260 \\
\hline Lactase & $79.15 \pm 2.06$ & $93.40 \pm 2.09 * *$ & $<0.001$ \\
\hline Sucrase & $84.50 \pm 3.51$ & $96.26 \pm 2.48^{*}$ & 0.016 \\
\hline
\end{tabular}

$$
\begin{array}{r}
482.16 \pm 8.67 \\
191.92 \pm 6.02 \\
2.55 \pm 0.10
\end{array}
$$

0.282

0.683

0.395

$a * P<0.05$ versus the CON group. ${ }^{* *} P<0.01$ versus the CON group. ${ }^{b}$ Values are the means of 16 replicates per treatment. ${ }^{c} \mathrm{CON}$, a cornsoybean basal diet; COS, chitosan oligosaccharide (the basal diet supplemented with $100 \mathrm{mg} \mathrm{kg}{ }^{-1}$ chitosan oligosaccharide). ${ }^{d} \mathrm{~V} / \mathrm{C}$, the ratio of villus height to crypt depth.
Table 8 Effects of chitosan oligosaccharide on the digestive enzyme activities of weaned pigs ${ }^{a, b}$

${ }^{a}{ }^{*} P<0.05$ versus the CON group. ${ }^{* *} P<0.01$ versus the CON group. ${ }^{b}$ Values are the means of 16 replicates per treatment. ${ }^{c} \mathrm{CON}$, a cornsoybean basal diet; COS, chitosan oligosaccharide (the basal diet supplemented with $100 \mathrm{mg} \mathrm{kg}{ }^{-1}$ chitosan oligosaccharide).

sucrase activity was higher in the duodenal and ileal mucosa, but not $(P>0.05)$ in the jejunal mucosa. Meanwhile, COS inclusion increased $(P<0.05)$ lactase activity in all of the selected intestine.

Table 9 Effects of chitosan oligosaccharide on the intestinal microflora of weaned pigs ${ }^{a, b}$

Bacteria content $(\lg ($ copies per $g))$

Treatments $^{c}$

\begin{tabular}{llll} 
Items & $\mathrm{CON}$ & $\mathrm{COS}$ & $P$-Value \\
\hline
\end{tabular}

Ileum

Total bacteria

Escherichia coli

Lactobacillus

Bifidobacterium

Bacillus

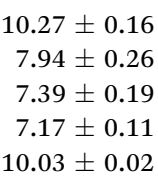

$9.87 \pm 0.16$

0.103

$7.43 \pm 0.25$

0.180

$7.54 \pm 0.14$

$8.18 \pm 0.32 *$

0.540

$7.17 \pm 0.11$

$10.18 \pm 0.09$

0.157

Caecum

Total bacteria

Escherichia coli

Lactobacillus

Bifidobacterium

Bacillus

$$
\begin{aligned}
11.58 & \pm 0.06 \\
8.66 & \pm 0.18 \\
8.51 & \pm 0.19 \\
9.72 & \pm 0.20 \\
10.08 & \pm 0.31
\end{aligned}
$$

\section{Colon}

Total bacteria

Escherichia coli

Lactobacillus

Bifidobacterium

Bacillus $a * P<0.05$ versus the CON group. ${ }^{*} * P<0.01$ versus the CON group. ${ }^{b}$ Values are the means of 16 replicates per treatment. ${ }^{c} \mathrm{CON}$, a cornsoybean basal diet; COS, chitosan oligosaccharide (the basal diet supplemented with $100 \mathrm{mg} \mathrm{kg}^{-1}$ chitosan oligosaccharide). 


\section{Intestinal microbial population}

As shown in Table 9, COS treatment markedly decreased $(P<$ $0.05)$ total bacteria and $E$. coli populations in the caecum and colon, while increased $(P<0.05)$ Bifidobacterium populations in the ileum. Furthermore, there were no differences $(P>0.05)$ in intestinal Lactobacillus and Bacillus populations between the CON and COS groups.

\section{Intestinal mucosal gene expression}

Tight junction proteins and glucose transporter gene expressions in the intestinal mucosal are shown in Fig. 2 and 3, respectively. In the jejunum, an increase $(P<0.05)$ in CLDN-1, OCLN and SGLT1 mRNA abundance was observed in pigs fed COS compared to the CON group. Additionally, no changes $(P>$ 0.05) in duodenal and ileal CLDN-1, OCLN, ZO-1, SGLT1 and GLUT2 mRNA abundance upon COS supplementation were detected.

\section{Discussion}

Oxidative stress is a general term that describes the imbalance between the relative levels of reactive oxygen species (ROS) and intra- and extracellular antioxidants wherein the amount of ROS is in excess. ${ }^{40}$ Numerous factors, such as weaning, environmental factors and infection, can induce oxidative stress, resulting in serious economic losses during livestock production. ${ }^{41,42}$ Natural antioxidants, such as COS, may be used to relieve oxidative stress in livestock production. ${ }^{43} \mathrm{MDA}$ is the most familiar breakdown product of lipid peroxidation and its level is frequently used as a direct marker of lipid oxidative damage caused by ROS. ${ }^{44}$ We observed COS supplementation can decrease serum MDA content in weaned pigs, thereby suggesting that COS could depress their lipid peroxidation. Scavenging capacity for free radicals is related to enzymatic and non-enzymatic antioxidant defence systems, which were measured to further identify the manner of COS-induced inhibition of oxidative damage. We observed an increase in serum SOD and CAT activities, which are representative enzymatic antioxidants in the body. ${ }^{45}$ Furthermore, T-AOC, a participant in the non-enzymatic antioxidant defence systems, ${ }^{46}$ was increased in the serum. These combined findings suggested that COS can protect weaned pigs against oxidative stress by improving their antioxidant defence systems functions.

Previous studies have demonstrated that dietary COS supplementation enhanced cell-mediated immune response in early weaned pigs by modulating the production of cytokines and antibodies. ${ }^{\mathbf{4 7}, 48}$ Here, we reported that serum IL-6, TNF- $\alpha$ and IgG levels, were markedly increased in COSsupplemented pigs, indicating that COS supplementation efficiently elicited a humoral immune response, which may provide an advantage in increasing weaned pig immunity. ${ }^{\mathbf{4 9}}$ Moreover, an increase in the sIgA content in the total small intestine was occurred, following COS ingestion. It is wellknown that sIgA serves as the first line of defence in protecting the intestinal epithelium from enteric toxins and pathogenic microorganisms. ${ }^{\mathbf{5 0}}$ Also, sIgA promotes the
A
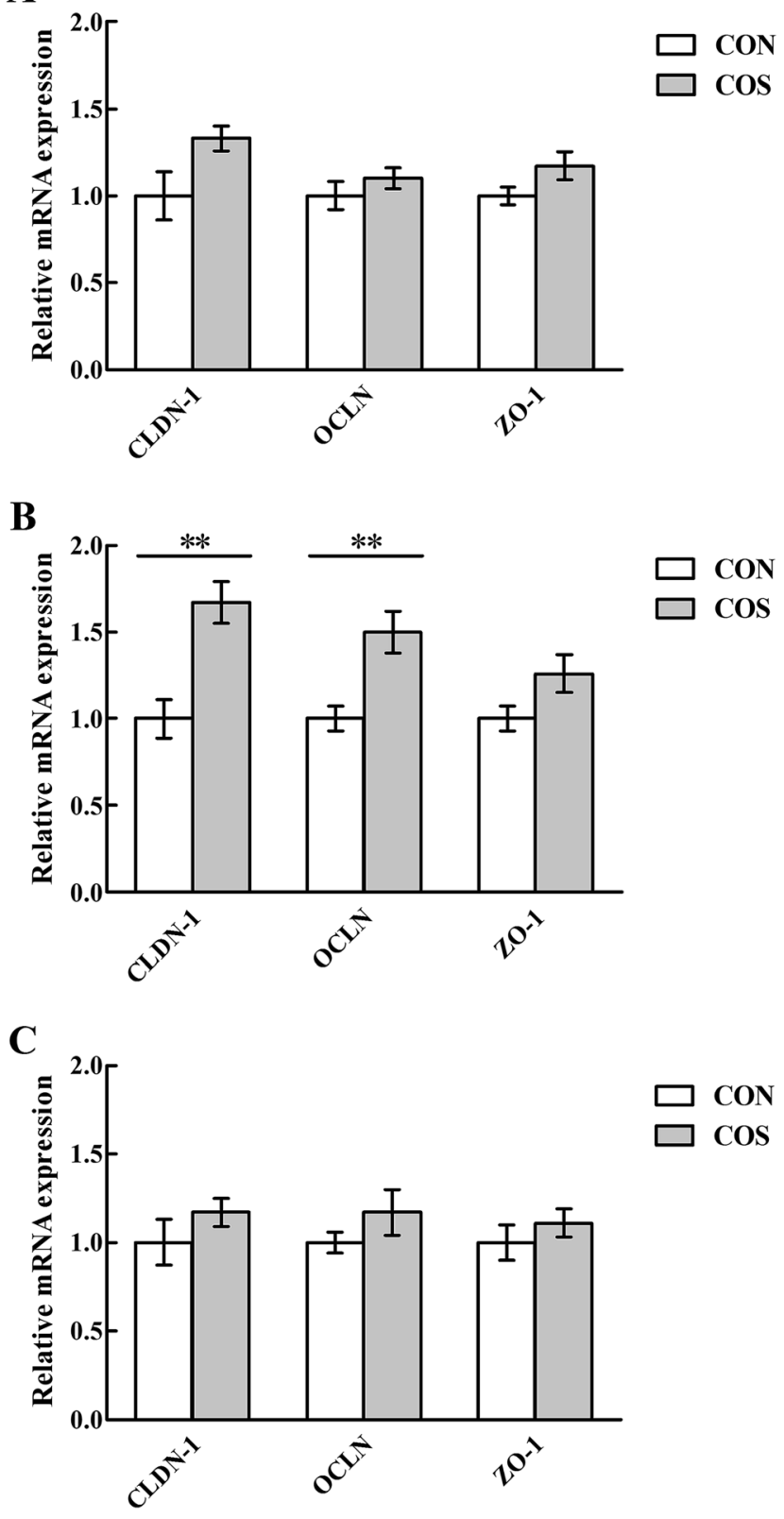

Fig. 2 Effects of chitosan oligosaccharide on the relative mRNA expression of tight junction proteins in the duodenal (A), jejunal (B) and ileal (C) mucosa of weaned pigs. Values are the means (16 pigs per treatment) with standard errors represented by vertical bars. ${ }^{*} P P<0.01$ (indicates that the relative mRNA expression of the tight junction proteins in the COS group is significantly higher than that in the CON group). CON, a corn-soybean basal diet; COS, chitosan oligosaccharide (the basal diet supplemented with $100 \mathrm{mg} \mathrm{kg}^{-1}$ chitosan oligosaccharide). CLDN-1, claudin-1; OCLN, occludin; ZO-1, zonula occludens-1.

clearance of antigens and pathogenic microorganisms from the intestinal lumen by blocking their access to epithelial receptors, entrapping them in mucus and thereby facilitating their removal by peristaltic and mucociliary activities. ${ }^{\mathbf{5 1}}$ Therefore, the increased intestinal sIgA content in the COS group indicated that COS can activate the intestinal mucosal 
A

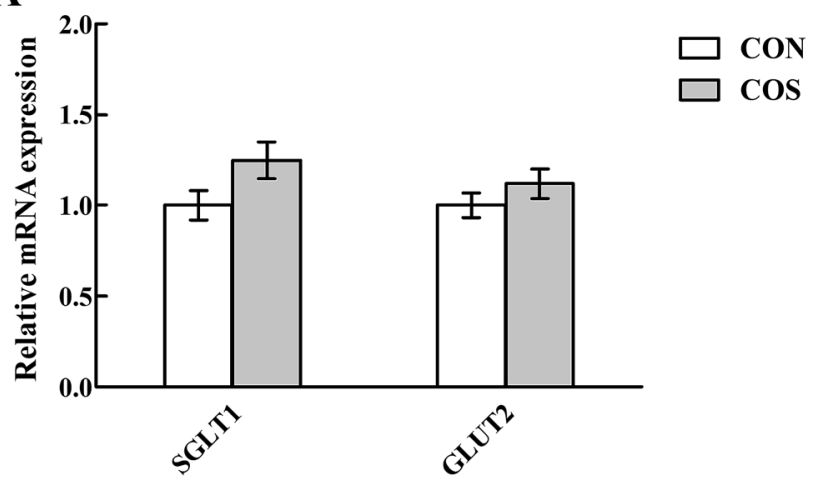

B

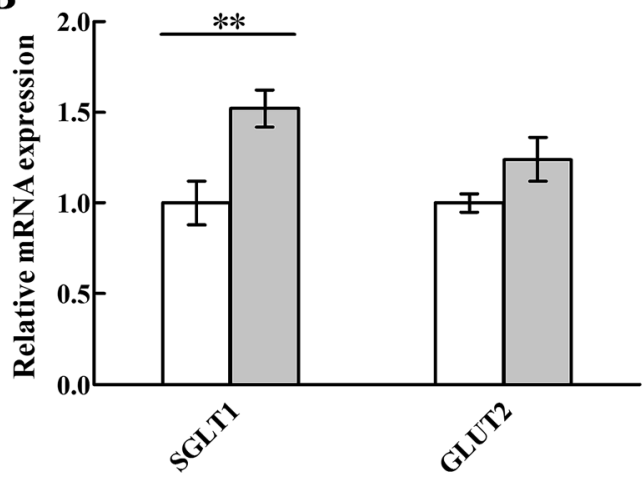

C

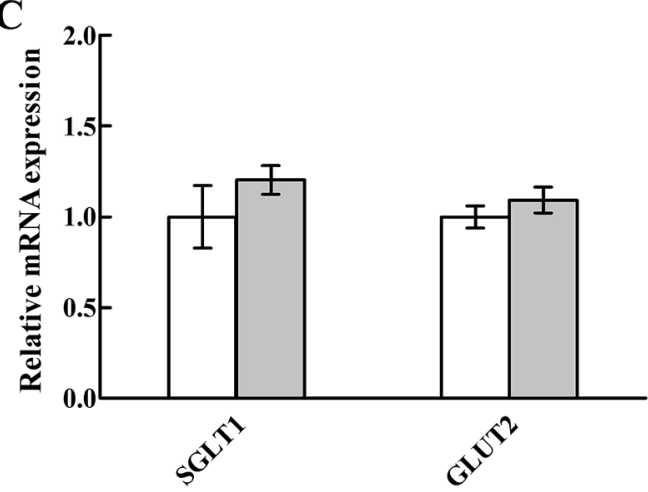

Fig. 3 Effects of chitosan oligosaccharide on the relative mRNA expression of glucose transporters in the duodenal (A), jejunal (B) and ileal (C) mucosa of weaned pigs. Values are the means (16 pigs per treatment) with standard errors represented by vertical bars. $* * P<0.01$ (indicates that the relative mRNA expression of the glucose transporters in the COS group is significantly higher than that in the CON group). CON, a corn-soybean basal diet; COS, chitosan oligosaccharide (the basal diet supplemented with $100 \mathrm{mg} \mathrm{kg}^{-1}$ chitosan oligosaccharide). SGLT1, $\mathrm{Na}^{+}$-glucose co-transporter 1; GLUT2, facilitated glucose transporter 2 .

immunity. As indicated above, COS played an important immunomodulatory role in pig immune function after weaning that is likely to be associated with changes in the intestinal and systemic immune network.

After weaning, villus height was generally decreased, whereas crypt depth increased, in association with a reduction in the nutrient digestion and absorption capacity. ${ }^{52,53}$ Consequently, maintaining intestinal structural and morphological properties for digesting and absorbing various nutritional substances after weaning is important. In the present study, greater villus height in the duodenum was found in pigs fed diets containing COS compared to the CON group. Based on the foregoing view, we showed that dietary COS can modulate intestinal morphological changes and, therefore, enhance nutrients absorption. In general, morphological changes in the intestinal tissue were accompanied by alterations in the activities of numerous brush-border digestive enzymes. On brushborder membranes, disaccharide enzymes (maltase, lactase and sucrase) serve important digestive enzymatic functions. By examining the intestinal enzymatic activities, we confirmed that COS significantly increased the lactase and sucrase activities in the duodenum. Meanwhile, we also verified an increase in the apparent digestibility of nutrients in COS-supplemented pigs, which could be due to the higher digestive enzyme activities and enhanced intestinal morphology. On the other hand, both a higher growth performance and apparent nutrient digestibility inversely supported the improved intestinal morphology and digestive enzyme activities.

Disturbances in the intestinal barrier, characterised by increased intestinal permeability, results in translocation of luminal bacteria, toxins and antigens into the subepithelial tissues, affecting nutrient absorption..$^{54,55}$ Therefore, an intact intestinal mucosal barrier is pivotal to ensure adequate provision of dietary nutrients to the whole body and to prevent gutrelated diseases. Weaning stress has been reported to cause remarkable disturbances in intestinal barrier function. ${ }^{56}$ Presently, we monitored the tight junction proteins, which function as a selectively permeable barrier within the epithelial cell space, ${ }^{57,58}$ to evaluate intestinal permeability. Accordingly, COS supplementation elevated jejunal CLDN-1 and OCLN mRNA levels in weaned pigs, suggesting that $\operatorname{COS}$ could ameliorate the weaning-associated damage to jejunal structural integrity by facilitating the tight junction protein expression levels in weaned pigs. Another intriguing new discovery in the present study is that the jejunal SGLT1 mRNA level was up-regulated when pigs were fed COS-supplemented diets. Recent studies indicated that SGLT1 is the rate-limiting step for absorption of dietary glucose from the intestinal lumen into the body. ${ }^{59,60}$ It appears, therefore, that COS could enhance the local glucose uptake of weaned pigs, allowing more energy for growth, which was a contributing factor in promoting growth performance by COS. Similarly, some other oligosaccharides, like cellooligosaccharide, have been shown to improve glucose absorption in the piglet small intestine after weaning. ${ }^{61}$

Intestinal microflora are crucial for maturation of the immune system and development of normal intestinal morphology. Oligosaccharides are usually defined as prebiotics that can selectively stimulate the growth of health-promoting bacteria. ${ }^{62,63}$ Our results demonstrated that weaned pigs fed $100 \mathrm{mg} \mathrm{kg}^{-1}$ COS inclusion in the diet, increased the ileal Bifdobacteria populations and decreased the caecal total bacteria and E. coli populations. One potential explanation is that a positive charge on the $\mathrm{NH}_{3}{ }^{+}$group of the GlcN monomer of COS allows interactions with negatively charged microbial cell membranes that lead to leakage of intracellular constituents. ${ }^{64}$ 
Another potential explanation is an indirect effect caused by increasing the Bifidobacteria populations and their subsequent competitive exclusion of E. coli. ${ }^{65}$ Furthermore, the intestinal microflora also affect the expression of intestinal tight junction proteins. For instance, $E$. coli has been reported to destabilise and dissociate CLDN-1, OCLN and ZO-1 tight junction complexes. ${ }^{66}$ In the current study, the increased tight junction protein expression levels in the COS group were in accordance with the decreased $E$. coli populations. Although great advances have been made in the rapidly growing field of nutritional biochemistry, there is a paucity of information about the specific molecular mechanisms that regulate the tight junction alterations by the intestinal microflora.

\section{Conclusions}

Our results demonstrated that dietary COS inclusion can improve weaned pig growth performance through enhancing weaned pig health status. The considerable benefits of improving weaned pig health status through COS supplementation, appear to be mediated through changes in antioxidant and immune status, as well as in intestinal development. This study provides new insights into the role of COS in enhancing growth performance, antioxidant capacity, immune function and intestinal development of weaned pigs. Furthermore, we enthusiastically predict that COS will widely become an antibiotic alternative for improving health and preventing infectious disease in both humans and animals.

\section{Competing interests}

The authors declare that they have no competing interests.

\section{Ethical approval}

All experimental procedures for the present study were approved by the Animal Management Rules of the Ministry of Health of the People's Republic of China and the Animal Care and Use Committee of Sichuan Agricultural University. We confirm that all experiments were performed in accordance with the relevant laws and guidelines.

\section{Acknowledgements}

We would like to express our deep gratitude to Kaiyun Yang, Huifen Wang and Quyuan Wang for their ongoing help during the experiments. We also convey our great appreciation to Likun Cheng, Heng Yin and Yuguang Du, from the Dalian Institute of Chemical Physics, Chinese Academy of Sciences, for preparing and measuring COS. This work was supported by the Special Fund for Agro-Scientific Research in the Public Interest (201403047), the National Natural Science Foundation of China (31372347) and the Fok Ying-Tung Education Foundation (141027).

\section{References}

1 J. Gong, F. Yin, Y. Hou and Y. Yin, Can. J. Anim. Sci., 2014, 94, 223-241.

2 J. Wan, Y. Li, D. W. Chen, B. Yu, P. Zheng, X. B. Mao, J. Yu and J. He, J. Microbiol. Biotechnol., 2016, 26, 461-468.

3 D. L. Smith, A. D. Harris, J. A. Johnson, E. K. Silbergeld and J. G. Morris, Proc. Natl. Acad. Sci. U. S. A., 2002, 99, 64346439.

4 K. N. Han, I. K. Kwon, J. D. Lohakare, S. Heo and B. J. Chae, Asian-Australas. J. Anim. Sci., 2007, 20, 556-562.

5 X. F. Kong, X. L. Zhou, G. Q. Lian, F. Blachier, G. Liu, B. E. Tan, C. M. Nyachoti and Y. L. Yin, Livest. Sci., 2014, 160, 97-101.

6 W. Kunanusornchai, B. Witoonpanich, T. Tawonsawatruk, R. Pichyangkura, V. Chatsudthipong and C. Muanprasat, Pharmacol. Res., 2016, 113, 458-467.

7 H. J. Yoon, M. E. Moon, H. S. Park, S. Y. Im and Y. H. Kim, Biochem. Biophys. Res. Commun., 2007, 358, 954-959.

8 S. H. Lee, M. Senevirathne, C. B. Ahn, S. K. Kim and J. Y. Je, Bioorg. Med. Chem. Lett., 2009, 19, 6655-6658.

9 J. K. Park, M. J. Chung, H. N. Choi and Y. I. Park, Int. J. Mol. Sci., 2011, 12, 266-277.

10 K. T. Shen, M. H. Chen, H. Y. Chan, J. H. Jeng and Y. J. Wang, Food Chem. Toxicol., 2009, 47, 1864-1871.

11 R. H. Huang, E. Mendis and S. K. Kim, Bioorg. Med. Chem., 2005, 13, 3649-3655.

12 P. J. Park, J. Y. Je and S. K. Kim, J. Agric. Food Chem., 2003, 51, 4930-4934.

13 Y. J. Jeon, P. J. Park and S. K. Kim, Carbohydr. Polym., 2001, 44, 71-76.

14 Y. Wang, P. G. Zhou, J. X. Yu, X. R. Pan, P. P. Wang, W. Q. Lan and S. D. Tao, Asia Pac. J. Clin. Nutr., 2007, 16, 174-177.

15 F. Karadeniz, M. Artan, C. S. Kong and S. K. Kim, Carbohydr. Polym., 2010, 82, 143-147.

16 J. C. Fernandes, P. Eaton, H. Nascimento, M. S. Gião, Ó. S. Ramos, L. Belo, A. Santos-Silva, M. E. Pintado and F. X. Malcata, Carbohydr. Polym., 2010, 79, 1101-1106.

17 S. Swiatkiewicz, M. Swiatkiewicz, A. Arczewska-Wlosek and D. Jozefiak, J. Anim. Physiol. Anim. Nutr., 2015, 99, 1-12.

18 T. X. Zhou, J. H. Cho and I. H. Kim, Livest. Sci., 2012, 144, 263-268.

19 P. Liu, X. S. Piao, S. W. Kim, L. Wang, Y. B. Shen, H. S. Lee and S. Y. Li, J. Anim. Sci., 2008, 86, 2609-2618.

20 J. P. Lallès, G. Boudry, C. Favier, N. L. Floc'h, I. Luron, L. Montagne, I. P. Oswald, S. Pié, C. Piel and B. Sève, Anim. Res., 2004, 53, 301-316.

21 J. R. Pluske, D. J. Hampson and I. H. Williams, Livest. Prod. Sci., 1997, 51, 215-236.

22 L. H. Zhu, K. L. Zhao, X. L. Chen and J. X. Xu, J. Anim. Sci., 2012, 90, 2581-2589.

23 B. A. Williams, M. W. A. Verstegen and S. Tamminga, Nutr. Res. Rev., 2001, 14, 207-228.

24 X. Xiong, H. S. Yang, X. C. Wang, Q. Hu, C. X. Liu, X. Wu, D. Deng, Y. Q. Hou, C. M. Nyachoti and D. F. Xiao, J. Anim. Sci., 2015, 93, 1089-1097. 
25 H. Zhang, Y. G. Du, X. J. Yu, M. Mitsutomi and S. I. Aiba, Carbohydr. Res., 1999, 320, 257-260.

26 National Research Council, Nutrient Requirements of Swine, National Academics Press, Washington, DC, 11th edn, 2012.

27 Standards press of China, Measurement of the Acid Insoluble Ash in Feed, GB/T 23742, Beijing, China, 2009.

28 AOAC, Official Method of Analysis, AOAC, Washington, DC, 16th edn, 1995.

29 X. D. Zhang, L. S. Cai and T. X. Wu, Aquaculture, 2008, 280, 136-139.

30 W. Cao, L. Xiao, G. M. Liu, T. T. Fang, X. J. Wu, G. Jia, H. Zhao, X. L. Chen, C. M. Wu and J. Y. Cai, Food Funct., 2016, 7, 2303-2311.

31 B. Özmen, D. Özmen, E. Erkin, I. Güner, S. Habif and O. Bayindir, Clin. Biochem., 2002, 35, 69-72.

32 D. R. Livingstone, P. G. Martinez, X. Michel, J. F. Narbonne, S. O'Hara, D. Ribera and G. W. Winston, Funct. Ecol., 1990, 4, 415-424.

33 X. Y. Dong, Y. M. Wang, L. Dai, M. M. Azzam, C. Wang and X. T. Zou, Poult. Sci., 2012, 91, 1886-1892.

34 M. M. Bradford, Anal. Biochem., 1976, 72, 248-254.

35 S. A. Bustin, J. Mol. Endocrinol., 2000, 25, 169-193.

36 J. Wan, Y. Li, D. W. Chen, B. Yu, G. Chen, P. Zheng, X. B. Mao, J. Yu and J. He, Anim. Feed Sci. Technol., 2016, 211, 216-226.

37 K. J. Livak and T. D. Schmittgen, Methods, 2001, 25, 402-408.

38 J. Wan, F. Jiang, Q. S. Xu, D. W. Chen and J. He, RSC Adv., 2016, 6, 87026-87035.

39 G. Q. Han, Z. T. Xiang, B. Yu, D. W. Chen, H. W. Qi, X. B. Mao, H. Chen, Q. Mao and Z. Q. Huang, Mol. Biol. Rep., 2012, 39, 1869-1876.

40 S. Reuter, S. C. Gupta, M. M. Chaturvedi and B. B. Aggarwal, Free Radical Biol. Med., 2010, 49, 1603-1616.

41 J. Yin, W. K. Ren, G. Liu, J. L. Duan, G. Yang, L. Wu, T. J. Li and Y. L. Yin, Free Radical Res., 2013, 47, 1027-1035.

42 G. M. Liu, T. T. Fang, T. Yan, G. Jia, H. Zhao, X. L. Chen, C. M. Wu and J. Wang, RSC Adv., 2014, 4, 56766-56778.

43 J. Wan, K. Y. Yang, Q. S. Xu, D. W. Chen, B. Yu, Y. H. Luo and J. He, RSC Adv., 2016, 6, 70715-70722.

44 F. Lin, S. Zhao, G. F. Chen, W. D. Jiang, Y. Liu, J. Jiang, K. Hu, S. H. Li and X. Q. Zhou, Fish Physiol. Biochem., 2014, 40, 499-510.

45 T. T. Fang, G. M. Liu, W. Cao, X. J. Wu, G. Jia, H. Zhao, X. L. Chen, C. M. Wu and J. Wang, RSC Adv., 2016, 6, 31323-31335.

46 W. Cao, G. M. Liu, T. T. Fang, X. J. Wu, G. Jia, H. Zhao, X. L. Chen, C. M. Wu, J. Wang and J. Y. Cai, $R S C A d v$, 2015, 5, 76607-76614.
47 Y. L. Yin, Z. R. Tang, Z. H. Sun, Z. Q. Liu, T. J. Li, R. L. Huang, Z. Ruan, Z. Y. Deng, B. Gao and L. X. Chen, Asian-Australas. J. Anim. Sci., 2008, 21, 723-731.

48 D. F. Xiao, Z. R. Tang, Y. L. Yin, B. Zhang, X. G. Hu, Z. M. Feng and J. Q. Wang, Int. Immunopharmacol., 2013, 17, 670-676.

49 P. Li, Y. L. Yin, D. F. Li, S. W. Kim and G. Y. Wu, Br. J. Nutr., 2007, 98, 237-252.

50 D. F. Keren, Am. J. Surg. Pathol., 1988, 12, 100-105.

51 N. J. Mantis, N. Rol and B. Corthésy, Mucosal Immunol., 2011, 4, 603-611.

52 Y. Wang, T. Shan, Z. Xu, J. Liu and J. Feng, J. Anim. Sci., 2006, 84, 2636-2641.

53 L. Montagne, J. R. Pluske and D. J. Hampson, Anim. Feed Sci. Technol., 2003, 108, 95-117.

54 A. T. Blikslager, A. J. Moeser, J. L. Gookin, S. L. Jones and J. Odle, Physiol. Rev., 2007, 87, 545-564.

55 Z. W. Sun, X. D. Wang and R. Andersson, Dig. Surg., 1998, 15, 386-397.

56 A. T. Blikslager, A. J. Moeser, J. L. Gookin, S. L. Jones and J. Odle, Physiol. Rev., 2007, 87, 545-564.

57 S. Tsukita, M. Furuse and M. Itoh, Nat. Rev. Mol. Cell Biol., 2001, 2, 285-293.

58 X. L. Li, S. Akhtar and M. A. Choudhry, BBA, Mol. Basis Dis., 2012, 1822, 196-203.

59 S. H. Zhang, Q. Yang, M. Ren, S. Y. Qiao, P. L. He, D. F. Li and X. F. Zeng, Br. J. Nutr., 2016, 116, 593-602.

60 A. W. Moran, M. A. Al-Rammahi, D. K. Arora, D. J. Batchelor, E. A. Coulter, C. Ionescu, D. Bravo and S. P. Shirazi-Beechey, Br. J. Nutr., 2010, 104, 647-655.

61 L. F. Jiao, Z. H. Song, Y. L. Ke, K. Xiao, C. H. Hu and B. Shi, Anim. Feed Sci. Technol., 2014, 195, 85-91.

62 G. R. Gibson and M. B. Roberfroid, J. Nutr., 1995, 125, 14011412.

63 L. F. Jiao, Y. L. Ke, K. Xiao, Z. H. Song, C. H. Hu and B. Shi, J. Anim. Sci., 2015, 93, 1157-1164.

64 H. Liu, Y. M. Du, X. H. Wang and L. P. Sun, Int. J. Food Microbiol., 2004, 95, 147-155.

65 C. M. Yang, P. R. Ferket, Q. H. Hong, J. Zhou, G. T. Cao, L. Zhou and A. G. Chen, J. Anim. Sci., 2012, 90, 2671-2676.

66 M. M. Muza-Moons, E. E. Schneeberger and G. A. Hecht, Cell. Microbiol., 2004, 6, 783-793.

67 H. Chen, X. B. Mao, J. He, B. Yu, Z. Q. Huang, J. Yu, P. Zheng and D. W. Chen, Br. J. Nutr., 2013, 110, 1837-1848.

68 H. Chen, X. B. Mao, L. Q. Che, B. Yu, J. He, J. Yu, G. Q. Han, Z. Q. Huang, P. Zheng and D. W. Chen, Anim. Feed Sci. Technol., 2014, 195, 101-111. 